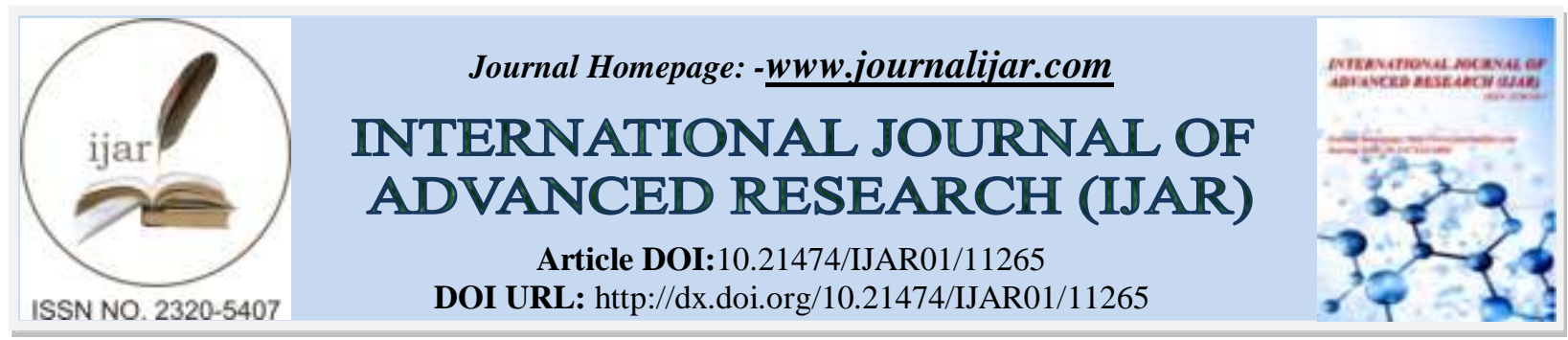

RESEARCH ARTICLE

\title{
EXTENT OF SCHOOL MANAGERS' UTILIZATION OF FUND GENERATION STRATEGIES FOR A SUSTAINABLE PRIVATE SECONDARY EDUCATION IN IMO STATE
}

Anyanwu, Jude Azubuike and Stanley U. Nnorom

Department of Educational Management and Policy Nnamdi Azikiwe Univeristy, Awka.

\section{Manuscript Info}

Manuscript History

Final Accepted: 10 June 2020

Published: July 2020

Key words:-

Fund Generation, Private Secondary

Education, Sustainable Education
Received: 05 May 2020

\begin{abstract}
The purpose of the study was to determine the extent of school managers' utilization of fund generation strategies for a sustainable and affordable private secondary education in Imo state. The study was guided by two research questions. Descriptive survey research design was adopted for the study. The population of the study consisted of 426 managers and proprietors of private secondary schools in Imo state. Proportionate stratified random sampling technique was used to get 276 private secondary school managers. Data collection was done using structured questionnaire of 20 items, which was validated by experts. Cronbach alpha was used for the reliability test and coefficient value of 0.80 and 0.78 were obtained for parts A and B respectively and the sum of the reliability coefficient is 0.79 . Out of the 276 copies of the questionnaire distributed, 268 were dully filled and collected representing 95\% return rate. Data analysis was done using mean and standard deviation. The findings revealed that managers and proprietors of private secondary schools to a high extent generate fund through internal and external strategies. Based on the findings, it was recommended that the ministry of education should be given them grants and also that they should continue to devise other strategies of funding their schools.
\end{abstract}

Copy Right, IJAR, 2020,. All rights reserved.

\section{Introduction:-}

Educational investment and development is an inevitable resource of national development. This is so because the impact of education has overwhelming influence in all human endeavors. Every nation of the world placed educational development at the top most level among other social service providers in the state. Abdulyaqin and Durosaro(2017) would say that the status of education as both a service and a business has made the educational sector retain a place of priority in the budgetary allocation of any national. The type of service provided by education is in different levels, thus in Nigeria, we have pre-primary, primary, secondary and tertiary educational levels. With the launch of UBE, and the policy to eradicate illiteracy and to ensure that all children of school age are in school, the government alone could not chatter for the provision of educational services in this country thus have allowed the participation of voluntary agencies and private partnership in education. To buttress this, Abdulyaqin and Durosaro (2017) opines that even though investment in education comes from both public and private bodies but it is the role of the government to create an enabling environment for private participation in the educational sector. Also the national policy in education (FGN, 2013) was quoted as saying 'government welcomes the participation of voluntary agencies, communities and private individuals in the establishment and management of secondary schools, 
state governments shall prescribe conditions to be met by the communities and others wishing to establish secondary schools'. This has empowered many agencies and private individuals into establishing their own secondary schools in the country.

It will be recalled that it was the early Christian missionaries that brought western education to Nigeria around 1870 prominent among them were the Roman Catholic Mission, the Church Missionary Society (CMS) and the Methodist missionary (Ikediugwu, 2007). They established, managed and funded many of these schools with little or no grant in aid from the government. But around 1970 the federal government took over all these schools. But with the introduction of Universal primary Education (UPE) in 1976, there was an explosion in enrollment and the government could not chatter for all the needs both in quality, infrastructure, and human and material resources provision. Private sector participation was once again invertible. In this recent time, gradually private secondary schools have taken its proper place in the provision of quality and competitive education in this country. These private secondary schools are missionaries and parochial (faith-based) schools while others are purely private individual schools. They missionary secondary schools are those schools that are established by some religious congregations in the church with the support of their parent body to provide educational services as way of evangelization and as an apostolate. While the parochial secondary schools are those established by the local ordinaries within their church to support and render service to the community. Then the private individual schools are that founded by some good spirited individuals who have love for education but most of them are more or less business oriented rather than service oriented.

Most people today prefer sending their children to private school than public school, to this effect there are serious competitions among private secondary schools within the state. Since this is the case all school proprietors and agencies have never left any stone unturned in the provision of the needed quality for a sustainable secondary education in its entire ramification so as to make them much attractive, marketable, durable and affordable all these are to ensure sustainability.

Sustainable secondary education as we know is that type of education which will continue to be relevant and meaningful with the trend of time. If all these must be put in place funding is very paramount and given the fact that most of these private individuals are capitalist who have seen education as a business investment, thus has made private school to become highly exorbitant and unaffordable for the average Nigerian. Therefore in order to build an affordable secondary education in the state different strategies for funding must be devised other the tuition fees. Funding involves art of making plan for the financial provision for the execution of project in an organization in order to render its goods and services effectively. It can be said to be a commercial activity of provision of services which are monetary oriented in an organization. This is an aspect of educational financing. According to Afolabi (2005) funding is regarded as the act of generation, distribution and utilization of funds within the educational system. Financing private educational institutions is a very capital intensive and multi- dimensional project. According to Nwafor, Uchendu and Akani (2015). It is a system of apportioning available capital belonging to an organization for meeting a need. Funding refers to a form of financial support that is given for the achievement of a project. According to the Online Business Dictionary (2013) funding is the provision of financial resources in order to meet a need, project or program. Money needed to run a project or program in the school may be raised from within or outside the school. The process of making the acquired funds available to the units that require them either in the short or long run is referred to as funding.

Fund generation strategies according to UNESCO cited in Abdrahman, Ngkim and Ngeoh (2015) and Ugwu and Nnebedum (2018) means a set of small-scale projects which generate income to the individual beneficiaries or groups, and on the other hand promote rights to self-determination and integration. For Hezron (2016), income generating strategies are those activities which can be undertaking by organizations so as to raise fund to enhance project or school finance other than the statutory allocation. Also according to Odundo and Rambo, (2013) schoolbased generating strategies play important role in education financing by enabling schools to absorb macroeconomic shocks without necessarily posing more financial obligation to parents.

There are two main strategies of income generation for an affordable private secondary school apart from the statutory tuition fees; they are internal investment and external investment strategies. Internal investment strategies or internally generated revenue strategies(IGR) or school-based income strategies are those agro-commercial investments which the school can undertake to generation some pet fund in the school. They include animal 
husbandry, farming, canteen, leasing and rental of school halls and premises for ceremonies, cybercafé, registering as UTME accredited center, school project exhibition and inter-house competitions/cultural day celebrations.

External investment strategies are other means of generating huge capital from outside the school for capital projects of the school; such means include endowment funds, donations from philanthropists and friends of the school, writing for grants from international partners/organizations, like World Banks, UNDP, UNICEF, etc. NGOs/Civic Society Organizations interventions, Contributions of Alumni Association, scholarship/adoption fund and Diasporas intervention and remittance.

Private secondary education have thrived and become the dream of many school children, their parents and other stakeholders in the state because of the gloom and beauty that go with them and the type of improvement and infrastructural developments than its counter public secondary education. This situation has moved the research into finding out the extent of utilization of different strategies for fund generation to build a sustainable and affordable secondary education in the state.

\section{Statement of the problem:}

Private secondary education in Nigeria and in Imo state in particular has become the dream of most Nigerian children and their parents. In most places they cannot be compared with the public secondary schools in terms of infrastructural and instructional provisions, conditions of service, environment and academic performance. Many people are wondering the magic amidst the state of the economy of this nation, private schools are thriving. It is a fact that no enterprise can function very well without mapping out a strategy for fund generation. Therefore there must be some strategies which these private schools have mapped for their survival. All these notwithstanding, there has been serious accusations leveled against these private secondary schools ranging from charging high tuition fees, extortion of students and turning into themselves to purely business center institutions for their proprietors and mangers thus losing the goal for which they were established. This unfounded situation has led the researcher into studying the strategies for fund generation for a sustainable and affordable private secondary education in Imo state.

\section{Purpose of the study:}

The main purpose of this study is to ascertain the extent of school managers' utilization of fund generation strategies for a sustainable and affordable private secondary education in Imo state.

Specifically, the study will find out the:

1. Internal investment (agro-commercial) strategies for fund generation for sustainable private secondary education in Imo State.

2. External investment strategies for fund generation for sustainable private secondary education in Imo state.

\section{Research Questions:}

1. To what extent do school managers' utilize internal investment strategies for fund generation for a sustainable private secondary education in Imo state

2. To what extent do school managers' utilize external investment strategies for fund generation for a sustainable private secondary education in Imo state

\section{Method:-}

The design for this study is descriptive survey research design. The total population of the study was 426 private secondary school principals, corresponding to the total number of private secondary schools in the state. The sample size consists of 276 private secondary school principals. A 60\% sample was gotten through proportionate stratified random sampling technique. This technique was adopted to ensure that the three different types of private secondary schools were represented in the same manner as their population appeared. Researchers developed instrument titled private school managers' fund generating strategies questionnaire (PSMFGSQ) was used for date collection. The instrument has three sections A and B clusters. Cluster A consists of 10 items bothering on agro-commercial investment fund generating strategies while Baluster consists of 10 items on external investment strategies for fund generation. In all the PSMFGSQ contains 20 items all structured on a four points rating scale at Very High Extent (VHE), High Extent (HE), Low Extent (LE) and Very Low Extent (VLE) weighted at 4, 3, 2 and 1 respectively.

The face validity of the instrument was established by two experts one from Department of Educational Management and Policy and one from Department of Educational Foundations all of Nnamdi Azikiwe University, Awka. To determine the reliability of the instrument it was pilot tested in Owerri Urban of Imo state. The instrument 
was administered to 20 principals in private secondary schools in Owerri Urban. The data obtained were correlated using cronbach alpha it yielded a reliability coefficient of 0.80 and 0.78 for parts A and B respectively and overall reliability coefficient of 0.79 . This was considered reliable as according Nworgu (2015) who stated that any instrument with a reliability coefficient of 0.60 and above is considered reliable. The instrument was administered by the researchers together with the help of three other research assistance. Out of the 276 copies of PSFGSQ distributed 268 were retrieved duly completed making a total of $95 \%$ return of rate. The data collected was analyzed using mean and standard deviations were used to answer the research questions. Mean score that fall between 4.003.50, 3.49-2.50, 2.49-1.50, and 1.49 below were taken to indicate VHE, HE, LE, VLE respectively.

\section{Results:-}

Research Question 1: To what extent do school managers utilize internal investment strategies for fund generation for a sustainable private secondary education in Imo state? Mean ratings and standard deviation scores of school managers on their extent of utilization of internal fund generation strategies for a sustainable and affordable private secondary education in Imo state

$(\mathrm{N}=26)$

\begin{tabular}{lllll}
\hline S/N & Items & mean & SD & Remarks \\
1 & Establishing of animal husbandry & 3.07 & 1.02 & High Extent \\
2 & Engaging in school farming & 2.92 & 0.92 & High Extent \\
3 & Opening of canteen services & 3.64 & 0.70 & Very High Extent \\
4 & Leasing and renting of sch. Facilities 2.84 & 1.07 & High Extent \\
5 & Opening of cybercafé & 2.34 & 1.09 & Low Extent \\
6 & $\quad$ Organizing of extra moral classes & 2.57 & 1.07 & High Extent \\
7 & $\quad$ School project exhibition day & 2.89 & 1.08 & High Extent \\
8 & $\quad$ Organizing inter-house competition & 2.91 & 0.96 & High Extent \\
9 & Opening of water vending service & 1.89 & 0.92 & Low Extent \\
10 & Engaging in school bus services & 3.35 & 0.80 & High Extent_
\end{tabular}

\section{Mean of Means} 2.84 0.96 High Extent

Result presented in table 1 showed that the mean scores of school mangers for items 5 and 9 are within the range of 1.50-2.49 indicating low extent of utilization of those strategies. Then item 3, with a mean score of 3.64 indicates a higher mean which implies that school managers make use of canteen services in their school to a large extent. The rest of the items mean scores indicate high extent of mangers utilization of those strategies. The pooled standard deviation score of 0.96 indicates convergence of their responses implying that their responses are homogenous. The mean of means of 2.84 which is in the range of high extent, meaning that school mangers' utilizes internal 
investment (agro-commercial) strategies to generate fund to ensure sustainability and affordability of their private secondary schools.

Research Question 2: To what extent do school managers utilize external investment strategies for fund generation for a sustainable and affordable private secondary education in Imo state?

Mean ratings and standard deviation scores of school managers on their extent of utilization of external fund generation strategies for a sustainable and affordable private secondary education in Imo state



Result presented in table 2, showed that the mean scores of school mangers for items 7 and 10 are within the range of 1.47-1.35 indicating very low extent of utilization of those strategies. Then item 4, with a mean score of 2.28 indicates low extent utilization. The rest of the items mean scores indicate high extent of mangers utilization of those strategies. The pooled standard deviation score of 0.99 indicates convergence of their responses implying that their responses are homogenous. The mean of means of 2.53 which is in the range of high extent, this means that school mangers' utilizes external investment strategies to generate fund to ensure sustainability and affordability of their private secondary schools.

\section{Discussion:-}

It was found out that there was high extent of school mangers' utilization of internal investment strategies. This finding is disagreement with Ugwu and Nnebedum (2018) who found out that secondary school principal have fully utilized internal investment (agro-commercial) strategies. This different could be because the type schools. But it is in agreement with Abdullahi and Abdulkareem (2017) who found out those agro- commercial strategies are alternative fund generation strategies for a sustainable universal basic education. This finding is not very surprising giving that fact they are private schools and in order to survive must adopt different means of generating fund. Every private school has the liberty to source for fund so that they could meet up with their demand and maintain their 
competitive standard. The finding in this study shows the extent of the utilization of the external investment strategies by the private school is high. This is supported by Nwakpa (2016) andAliyu (2018) who uphold these strategies as means of financing secondary education. This finding shows that private school especially the ones owed by the missionaries receive much funding through their parent organization and other international partner and other donor agents, donations from friends of the school, benefactors and other diaspora intervention. While most of the parochial schools receive funding from their immediate local communities. Majorly they access loan facilities and alumni association intervention are strong strategies of funding for private secondary schools in Imo state.

\section{Conclusion:-}

Based on the findings of this study, it is concluded that private school mangers in Imo state to very high extent make sure of both internal and external strategies to generate fund to sustain their school and thus make it affordable for parents. Otherwise they will have to pay highly to access secondary education.

\section{Recommendations:-}

The following recommendations were made based on the findings of this study:

1. That the ministry of education should as a matter of fact be given certain percentage of soft grant in aid to these private secondary schools as they are partners in the provision of educational services in the state.

2. They should continue to devise further means of generating fund so as to leverage on those financial prospects to make their schools much more affordable.

3. The managers of the schools should as a matter of necessity utilized fund generated to meet the minimum standard of education.

\section{References:-}

1. Abdrahman, A., Ngkim, S. \& Ngeoh, P.T. (2015). Income generation activities among academic staff at Malaysian public Universities. International Education studies, 8(6). 19203.

2. Abdullahi, N.J.K. and Abdulkareem, A.Y. (2017), Strategies for Financing Universal Basic Education for Sustainable National Development in Nigeria journal of Education policy http.//nau.edu/COE/journal/

3. Abdulyaqin. T. M. \& Durosaro, D. O. (2017). Educational Financing in EducationalManagement: New perspectives. Olubor. R. O., Abdulkareem, A. Y., Alabi, A. T \& Adeyanju, F., in (eds.) Lagos: Amfitop Nigeria LTD.

4. Afoalabi, S. O. (2005). Economics of education: scope of economics of education.

5. Ilorin: Integrity publishers.

6. Aliyu, B. B. (2018), Assessment of financial management practices among secondary school principals kaduna state. International journal of hospitality \& tourism management. (2). 2,

7. doi:10.11648/j.ijhtm.20180202.11

8. Busines Dictionary (2013). Fundinhttp://www.businessdictionary.com/definition/

9. funding.html

10. Federal government of Nigeria (2013) National policy on Education. Lagos.

11. Hezron, N. N. (2016). An evaluation of income generating projects in public secondary schools in Nairobi County. International Journal of

12. African and Asian Studies, 21: 6-16

13. Ikediugwu, N. P. (2007). Educational Financing and School Business Management. Enugu: Cheston Agency LTD.

14. Nwafor, E.N., Uchendu, E. Eand Akani, C. O. (2015), Need for adequate funding in the administration of secondary education in Nigeria. global journal of educational research. vol. 14, 2015: 119-124

15. Nwakpa, P. (2016); Alternative sources of financing secondary education in Ebonyi State by the school administrators. British Journal Education. Vol. 4, (4),

16. Nworgu, B. G. (2015). Education Research: Basic issues and Methodology.

17. ( $3^{\text {rd }}$ ed.). Enugu: University Trust Publishers.

18. Odundo, P. A. \& Rambo, C. M. (2013). Effect of school-based income generating activities on financial performance of public secondary schools in Kenya. Chinese Business Review, 12(6), 375-394

19. Ugwu, I. and Nnebedum, C. (2018). Analysis of income generating activities of

20. Anambra state secondary school principals as funding strategies in a depressed economy. Unizik Journal of Educational Management and Policy. Vol. 2 (1). Pp. 131-138. 